\title{
The Metamorphosis of Normative Feminism in Pride and Prejudice as Descriptive Feminism in Beloved: Inevitable Path of a Woman
}

\author{
Mahmoda Khaton Siddika
}

Lecturer in English, IIUC Bangladesh

Doi:10.5901/mjss.2013.v4n13p425

\begin{abstract}
Jane Austen in Pride and Prejudice and Toni Morrison in Beloved view normative and descriptive feminism especially through the character analysis of Elizabeth and Sethe. Austen presents Elizabeth through the normative feminist view as a woman with the power to judge the situation, to make opinion and to take the decision according to her understanding and intelligence. In the male-oriented society, she establishes herself as an independent being and challenges the second-rate woman concept. On the other way, Toni Morrison views that Sethe moulded by normative feminist characteristics fells herself as a topic of descriptive feminist concept- woman of inherited identity who has to make herself weak and subordinate to man in every aspect. Having strong determination and capacity of getting freedom, her struggle to stand independently causes her isolation from the male-centred community which leads to her distract mentality and incapability to breathe in this society. This paper aims at presenting Elizabeth as an unequivocal voice and model of normative feminist view to exert woman as equally capable, qualified, respected and important being as man. The paper also aims at showing how Elizabeth with normative feminist quality in Pride and Prejudice has been transfigured as Sethe with descriptive feminism in Beloved, whose struggle to lead an independent self and to exercise her potentiality as woman self is hindered by male mechanism which is an inevitable path of a woman.
\end{abstract}

Keywords: Feminism, Normative feminist view, Descriptive feminist view.

Jane Austen's Pride and Prejudice through narrative feminist view deals with the continuous effort of a teenage girl and heroine of this novel, Elizabeth, to live in a male-oriented community and to establish herself as an independent self and an archetypal of female world. She possesses unconventional characteristics of intelligence, impertinence, ingeniousness and dedication in her time, because Swords(2012) in "Woman's Place in Jane Austen's England" states that " some late eighteenth century authors of advice to girls and young woman regarded woman's minds as limited in reason and not to be overtaxed with serious, intellectual education". Jane Austen juxtaposes the perfect lady and Elizabeth by proving the views of some writers in Enlightenment period that "men and women", also says Sword, "were equally endowed by Providence with reason and moral nature and capacity. Thus, girls and woman must be taught to exercise their reason- must be taught to think- and must be educated to make sound moral judgment". Elizabeth, an exceptional female character having intelligence and reason, confirms her view over man's decision. But her refusal of male decision and her challenge to male expectation turn herself into a woman who has to always centre on the male decision like Sethe, protagonist in Beloved who possesses normative characteristics, like her. Toni Morrison in Beloved expresses through the descriptive feminist view that Sethe surrounded by men cannot breathe in single moment independently though she tries to. Having initiatives, courage, intelligence and knowledge of independent self, like Elizabeth, the compact fence of male community does not give her chance to attain her dignified self. Rather, this male community turns her all qualities into her confused mentality which does not make her daughter, Beloved, live with her, as Maitrise (2013) in "The Multidimensionality of the Woman's Victimhood in Toni Morrison's Beloved and Bessie Head's A Question of Power" exposes that "Beloved shares many a point with Morrison's other texts, particularly black life in a white system and female oppression in a patriarchal society". Her failure to stand in own way happened for the male patronized society creates a dangerous path for her another daughter, Denver. Even, she is not able to pave her own future with her daughter; rather her future depends on practical and trustworthy activities of a male, Paul D.

Out of practical inequality, Feminism emerges in reality to establish woman's equality with man. Along with this, it tries to alter the prescribed outlook regarding woman to put forward the real woman. So, it evolves with two conceptsNormative and Descriptive Feminism. Normative Feminism claims woman's right and respect equally on the basis of justice and morality, just like as man. It definitely tries to uphold the general characteristics of woman that woman is like 
Mary. But, Descriptive Feminism means that woman is deprived of the treatment and recognition what Normative Feminism theorizes. It exposes the reality of a woman disadvantaged with equality and dignity compared with man.

\section{Literature review of Normative and Descriptive Feminism}

Feminism can be defined in many perspectives-historical, political and cultural ways. Basically, Feminism historically raises its elevation by arguing with the fundamental exercise, Muji (2012) in "Gender issues reflected with nature in Jane Austen's novel Pride and Prejudice" tells that " ... their ( women) lack of freedom in a male dominated society: In all cases, her identity and her fate are defined and controlled by men-by fathers, husbands or seducers" and Abrams(1993) in his A Glossary of Literary Terms unearths that Woman is considered " as merely the negative object, or 'Other', to man as the defining and dominating 'Subject"' (Abram 234). Moreover, politically, feminism is based on, Muji in his essay says, the inequality between man and woman "is not the result of biological necessity but is produced by the cultural constructions of gender difference". Regarding Normative Feminism, it is said in Stamford Encyclopedia of Philosophy titled "Topics in Feminism" that "the normative claims concern how woman ought (or ought not) to be viewed and treated and draw on a background conception of justice or broad moral position". Muji also exposes that "woman must first venture out of the box and then struggle to change the attitudes in society" and establish themselves as competent, dignified self in society. In "Introduction: Theories of the Fantastic and feminist Narrative Theory- An Intersection", it is exposed that "it is through narrative that women most often become woman, [...] that process can be fractured through woman's self-representation". As a representative of normative feminism, Jane Austen makes, Nilsson (2012) explores in "The accomplished Woman- No Changes Accomplished? A comparison of the Portrayal of woman in Jane Austen's Pride\& Prejudice and Helen Fielding's Bridget Jones" that "Elizabeth a strong character who does not pay much attention to what other people think of her but stands up for her opinions".

In another way, in "Topics in Feminism", it is viewed that "descriptive claims concern how women are, as a matter of fact, viewed and treated, alleging that they are not being treated in accordance with the standards of justice or morality invoked in the normative claims". Nilsson also finds out that "conservative writers 'render woman more artificial, weak characters, than they would otherwise have been'" Abrams also exposes that "as Semone de Beauvoir put it, One is not born, but rather becomes, a woman...It is civilization as a whole that produces this creature... which is described as feminine" (235). In society, woman is barred by sex and economic status. In "Mothering Modes: Analyzing Mother Roles in Novels by Twentieth-Century United States Women Writers", McDaniels( 2013) states that "if race becomes another barrier for women who are negotiating their way in this patriarchal, white, middle-class dominated society, it only exacerbates the mothering situation". This is the condition of Sethe in Toni Morrison's Beloved. As a salve, Sethe has to go through all kinds of torture of her master and as a woman is oppressed by her male circumstances. Daniel (2013) in " Power and its Price: Female roles and the consequences of gaining agency in Toni Morrison's Beloved and Jane Smiley's A Thousand Acres" states that "Sethe's young experiences impress upon her the peril she is in not only as a slave, but also as a woman. Even as a girl, Sethe begins to understand how slavery is especially brutal towards mothers". So, Sethe having normative feminist characteristics, like Elizabeth, becomes the topic of this descriptive feminism and is in the process of dehumanization triggered by the white male oppressors and in the harm done by the male dominated community. So, as an individual, as a family member functioning as mother and daughter and finally as a beloved and wife, I have tried to present in this paper that Elizabeth is equivocal of Normative Feminism and Sethe possessing Elizabeth's qualities becomes a proper example of Descriptive Feminism showing the prevailing inequality of woman with man.

Jane Austen in her timeless classic, Pride and Prejudice, presents Elizabeth as embodied with normative feminist concept because "All this,[ knowledge of music, singing , drawing, dancing]" (35) "she must possess...and to all this she must yet add something more substantial, in the improvement of her mind by extensive reading" (35). Nilsson exposes that "this is also part of the fact that Austen's artistic choices emphasis Elizabeth's intelligence and humour [...] rather than her physical appearance ... thus making the heroine a character with more depth". Ignoring all preconceptions of woman of how a woman should behave, the novel's protagonist, Elizabeth places herself as rational, responsible being. Muji again explores that "she acts polite and ladylike but she is still her own individual and does not want to be submissive as woman are supposed to be in her society". She establishes herself as competent and reliable as man in her family. Elizabeth holds her own place in her family by dealing all kinds of family problems and concerning her family 
future, which denies the popular concept of male member's responsibility in family maintenance. Her watchfulness and caution for the family is evident in her awareness of the coming danger related to Lydia when she decides to go to Brighton with her friends. For this, she urges her father, Mr. Bennet, not to give his consent and consults on the remedy of Lydia's "unguarded and imprudent manner" ( 189). Only her own intelligent decision brings the wellbeing and stability of her family at last. She shocks at the news of Lydia's elopement with Wickham without marriage and tries to solve the problem by assigning this task on her reliable, intelligent and sensible uncle, Mr. Gardiner. After attaining proper reliability over Mr. Darcy, she discloses the matter of Lydia which paves the way of solving this problem. As a guardian of her family, she assures Lydia's financial security after her marriage even being a woman.

Moreover, her respect for her elder sister, Jane, heightens the honour of a woman, "you are too good. Your sweetness and disinterestedness are really angelic; ... I feel as if I had never done you justice, or loved you as you deserve" (114). As a human being, she becomes angry and indignant of knowing the involvement of Darcy to destroy her darling sister's happiness, "Mr. Darcy's shameful boast of what misery he had been able to inflict, gave her a keener sense of her sister's sufferings" (156) and is unable to concentrate on anything. She feels Jane's pleasure to dance with Bingley twice and concerns for her sister's health and Jane's worriedness and compassion for the detachment with Bingley. Her guardian-like dealing of her elder sister's relation with Bingley raises woman's position. Moreover, she is joyous for the happy news of her family. Lydia's marriage with Wickham, though "that they should marry, small as is chance of happiness" (245), and Jane's renewed relation with Bingley make her so much happy and give relief. Her dedication, concern and intelligent supervision about her family are akin to normative characteristics of a woman. Elizabeth, as an example of normative feminism, thinks not only of herself but also of others. So, she integrated with these qualities attains respected and responsible position in family as man is usually thought to attain.

Beloved which won the 1993 Nobel Prize for literature and the 1988 Pulitzer Prize for fiction, presents Sethe, protagonist and black woman slave, as a perfect example of descriptive feminist view in spite of having normative feminist characteristics, like Elizabeth. Morrison describes the real story of fugitive slave Margaret Garner in the story of Sethe in Beloved. She is presented, as Mayfield(2013) in "Motherhood in Toni Morrison's Beloved: A Psychological Reading" states, "as a woman of remarkable stillness, suggesting that she was calm and deliberate in difficult situations, as well as suggesting that she had cultivated the kind of practical rationality that would allow her to survive in a hostile culture". Mayfield again expresses that "Sethe, whose behavior demonstrated her will to succeed... continued to define herself as an individual, ... but also as a woman who looked toward a future with her husband and her children".

But, this woman is victimized of the cruel man-made society, though she struggles to hold the independent self as a woman. Sethe moulded by normative feminist characteristics is sensible to realize the erosion of her black female self at Sweet Home, as the white man perceives black female like animal, because as a representative of African American woman, slavery aims at her. In her book Circles of Sorrow, Lines of Struggle, Grewal (1998) theorizes that Beloved shows woman is the "subjects of rape, enforced childbirth, and natal alienation from their children" (Grewal 100) under slavery. Though many critics think of Sethe as a victim of racism, we see that slave-woman is more oppressed than slave-men. Hooks (1982) in Ain't I a Woman: Black Woman and Feminism states that "the lot of the black slave woman would always be harsher, more brutal than that of the black male slave" (Hooks 43). Horvitz( 1989 ) points out that " enslaved woman, not in possession of their own bodies, survived barbaric beatings, rapes, and being 'swallowed'...The price they paid was... an enormous one; those that survived often did so with no shred of basic integrity or dignity regarding their bodies" ( Horvitz 101). Moreover, Bjork (1992) expresses that "Black women, in the midst of both racism and sexism, did survive" (Bjork18). The brutal nephews of schoolmaster inscribe in their notebook the animal characteristics of Sethe. Her sensible awareness of her black female self and her boldness to reject white man's perception of herself confirm her decision to run away from Sweet Home plantation for the sake of her kids' future. Out of her sense of responsibility towards her children, without her husband's help she steps over the path of male dominated society in which she is considered as an animal. Banumathi (2012) in "African American Feminist consciousness in Toni Morrison's Beloved" expresses that "The feminist qualities that Morrison advocates through Sethe's portrayal are the traditional beauty, strength, resistance and integrity of black woman... In her interview with Rosemarie K. Lester, Morrison expresses her views ... black woman have always been both mother and labourer, mother and worker , and have worked in the fields along with man....Black woman both ship and safe harbour".

So strong-willed person she is during her escape. Sethe crawls towards the river, pregnant, desperate to reach other babies who are already in Ohio with Baby Suggs. Mayfield also says that "Sethe's miraculous escape in spite of this profound suffering and this murderous assault on her body was a testament to the stillness of her soul and strength". In other way, her way of naming of her children is her quality of self-acknowledgement because in "Call Me My Name: The Role of Nomenclature in Toni Morrison's Beloved" it is said that "Morrison uses the process of naming to show 
women are oppressed in a predominantly patriarchal society... Women are the lowliest members of society- AfricanAmericans occupy an unenviable rung of the social ladder, but to be an African- American woman means that you do not feel free to make even the smallest( yet most intimate) decisions (e.g., naming your child)". But, Sethe as a woman with typical masculine characteristics and with dignified self to live independent way has to live in a house of 124 Bluestone Road in Ohio "palsied by the baby's fury at having its throat cut"(5) and by the memory of ten minutes of her act of infanticide. Besides, her sense of independence makes herself realize that "Freeing yourself was, one thing; claiming ownership of that freed self was another" (95) in fence-based male society. Her claiming herself does not observe celebration because the unwritten codes of community does not accommodate with this situation. Her normative feminist character turns her as an example of descriptive feminism. Baby Suggs' announcement of the arrival of her daughter-inlaw is resentful to community because it thinks this of her prideful behavior- to cross the boundary of its prescribed pleasure, "Her friends and neighbors were angry at her because she had overstepped, given too much, offended them by excess" (138).

Her radical resistance does not erase the ink's inscription on school teacher's book but instead, it engraves this inscription in her memory. But when she moves from the centre of community, she falls into the hole of haunting place. Genetic ism of man confines Sethe's society so tightly that she is treated by her sons as society's prescribed woman. So, she is unlucky to have two sons with male mentality to consider woman as inferior and boring self. They even do not cope with mother and sister as woman, so they do not feel any dedication to their mother and sister, "Buglar and Howard grew furious at the company of the woman in the house, and spent in sullen reproach any time they had away from their odd work in town carrying water and feed at the stables" (104). Observing all happenings in her life, Sethe makes herself subordinate to man in every sense in this way that she has to comply with the society's pressure- no right to know about the filial bond with her mother. Costa(2012) in "Unspeakable Things (Un) spoken: the representation of Black Women in Toni Morrison's Beloved" says that "slave narratives presented black woman as so completely victimized that the experiences which slavery engendered and their ability to survive such experiences placed them outside what was accepted as the normal sphere of woman". She cannot break the popular concept of woman, rather, she is forced to follow the backboneless womanhood, to accept man's subjugation and becomes "a woman who lit up for nobody in particular, who just did it as a general announcement" (65) and "witless colored woman" (66).

Elizabeth as a topic of normative feminism justifies herself as unconventional lady that a woman can do what a man can, as she tramps across the fields so far alone in Bingley's house at Netherfield. Her living in Bingley's house at Netherfield shows her intelligence, her spirit and quickness of thought to converse with Darcy. Her mother's uncivil, rude and ignorant attitude is covered by her quickness of thought or intelligence. Her clear-sighted analysis of Darcy's letter confirms her intelligence and her willingness to value other's view. Her keen ability for perception soon justifies her family members' low and rude activities which are overlooked for her love for family. She with readiness of mind acknowledges Jane's failure to show her true feelings towards Bingley. Moreover, she painfully analyses her members' fault which are "hopeless of remedy" (175). In another case, Elizabeth's reaction to resist Lady Catherine's overbearing restores her own dignity. Though she feels insulted by Lady Catherine's impertinent questions about her family, she makes herself honour to manage the situation by being remained polite. Her refusal to give direct answer on her question of her age proves her ability to stand up against any kind of her insult and shows her a superior sense of value. Moreover, unexpected meeting with Lady de Catherine at Longbourn, Elizabeth very rationally and skillfully demolishes each questions of her. She is well aware of her family's shortcomings but she does not allow other to justify this matter, "you can now have nothing farther to say... You have insulted me, in every possible method. I must beg to return to the house" (288). In warning of her not to cross her limitation of her family, she tactfully holds equality with Darcy, "In marrying your nephew, I should not consider myself as quitting that sphere. He is a gentleman; I am a gentleman's daughter; so far we are equal" (287). In "What is feminist literary criticism? How does this apply to Pride and Prejudice?" it is told that "To be equal to and have equal opportunity and rights with a man of such social ranking as Mr. Darcy is to epitomize the very cause of feminist literary criticism - to chiefly advocate for the rights and equality of woman". She downrightly rejects her threat not to engage with Darcy by saying "I will make no promise of the kind" (287) which is right decision on marrying Darcy. She takes command on her by showing her liveliness, her integrity and proper intelligence. She shows that anyone cannot hinder her from rightful actions.

Overcoming woman's position as emotional sex, Sethe with normative characteristics manages her matriarchal position but Schoolteacher's invasion to capture her children stops her individual managing self, makes her a topic of 
descriptive feminism and paves her way to the point of insanity. Primlyn (2013) in "The Concept of Blackness in Toni Morrison's Beloved" says that "Sethe wants her children to be free. She refuses to accept the "silent second class status"'. Her step to rescue her children from perpetual slavery and physical assault by killing them on 124 Bluestone Rd. on an August afternoon in 1855 is one kind of protection from "a gang of whites invade her daughter's private parts, spoiled her daughter's thighs and threw her daughter out of the wagon" ( 251). Next, Sethe's explanation for rearing up the mysterious Beloved is that she fears of white man's "jump on a homeless, wandering black girl" (68). In "My Girl Come Home: Reading Beloved" it is said that it is for "the overarching horror of being raped and dirtied by whites" (Plasa 1998: 57).

Even, Sethe has gathered experience from her life that woman is victim of the sexual exploitation of male society since she always faces this at Sweet Home in which "two mossy-toothed boys" (70) hold Sethe down and suck her breast milk. As a woman and slave, Sethe has to transform her body to commodity where she has to give her body to white man's sexual inscription. When School teacher invades her family, "she flies...The ice pick is in her hand" (309). She is willing to kill other children to protect her family which shows her ability to stand in the society independently. Though it is cruel method, the cruel male oriented society hinders her to search out the some other way for this work not killing them, because she exposes to Paul D that this dangerous and murderous society breaks her two feet into several feet. Her limitation of knowledge on her children's safety acquired through the cruel male-centred society is "to get to a place where you could love anything you chose- not to need permission for desire-well now, that was freedom" (162). She starts her life as a soldier trying to protect her family. She thinks she does her own duty towards her children "to keep them away from what I know is terrible" (165) and it gives her peace that "they ain't at Sweet Home. School teacher ain't got em "(165).Adhikari ( 2002) in "The Female Protagonist's Search for Wholeness and Toni Morrison's Discourse in Beloved" expresses that "foolishly she considers herself to be a human being and mother but her euphoria lasts for a brief period" ( Ifran). After this event, her heroic deed of resistance and her dream to survive without the help of others makes herself a lone warrior against the rest of the world. The community discards her as an outcast. She becomes victim of her past and present horror inflicted by male surroundings- school teacher, the prison and other white horrors, and has to claim her subjectivity to her society, though she has conviction and desire to be free and has ingenuity to cultivate her personal freedom, like Elizabeth.

For pressure from male community, she does not control the aftermath of her infanticide and does not give a convenient atmosphere for Denver with proper explanation of her action. She is well aware of the impotence of her word which is unsupported by community, "Sethe knows that the circle she was making around the room, him, the subject would remain one. That she could never close in, pin it down for anybody who had to ask. If they didn't get right off-she could never explain" (163). Being expressionless and directionless, her failure of giving exact answer of a question of Denver's school boy Nelson Lord whether it is true that Sethe murders her baby sister forces Denver to stop her schooling and to live in an isolated world away from human community for almost two years. As a mother, Sethe oriented with male subjugation cannot give her daughter a pleasurable moment except her bundle of failure and impetus to her daughter to exercise the independent sense of woman self. Denver needs "some body normal in her life" (170)'. Sethe can not be that person because she herself is in the haunts of spirit. As a mother, the memory of killing her own child is dangerous and tempting for Sethe. And the detachment from human community creates her spiteful behaviour, sensitivity and her eagerness for ghost's presence.

Sethe's attempt to rescue her children from slavery or slave oppression and sexual harassment leads her into the bottom of male machine hole where she cannot find the secure place for her daughter; rather, Denver becomes "Ionesome. Very lonesome" (55) and "a girl who had lived all her life in a house peopled by living activity of the dead" (29). Though she attempts to improve her life observing Sethe's degenerated condition, she has to "inaugurate her life in the world as a woman" (248). Sethe as a suffocating mother, does not be the safeguard of Denver to place her away from her own place of subjectivity. Morrison describes Denver's subjective destitution writing, "Now [Denver] cries because she has no self" (123). Dueker (2012) in "When a Man Becomes a Woman(And Vice Versa) upholds that "Sethe is no longer competent and able to take care of multiple people; she cannot even take care of herself". Her daring to be capable and her masculine ways face punishment from her community. All the traits of her powerfulness are banished for the pressure of society. According to Morrison, neither mother nor her child can be benefited from this contaminated male society because her future plan is "a matter of keeping the past at bay. "The "better life", she believed she and Denver were living was simply not that other one" (42). Her tendency to hold individual attempt for protecting her child in her own way- "I'll protect her while I'm live and I'll protect her when I ain't"(45)- does not come to true for the difficult hindrance of the male society. Her way of method for the safety of her children which the cruel male society does not understand creates even difficult position which Paul D analyses correctly, " for a used-to-be-slave woman to love 
anything that much was dangerous, especially if it was her children she had settled on to love" (45), Heinert (2008) asserts in Narrative Conventions and Race in the Novels of Toni Morrison that "Slavery interferes in filial relationships to the extent that even the natural emotion of loving one's children is dangerous" (Heinert 2008 ).

III

Continuously, Elizabeth falls in a topic of normative feminism in the understanding of life. Elizabeth as a perfect woman is bold enough to express her thoughts and views of life in a liberal way. Tanrivermis (2013) in "Female Voice in Jane Austen: Pride and Prejudice and Emma" exposes that Elizabeth's wit and her unconventional and liberal talks signal the clues about the exposition of female identity...confident in conversations and sure of her opinions, Elizabeth does not hesitate to convey either her certainty or her views". Elizabeth's efforts to place woman dignity and individuality in the matter of love and marriage show her equality sense with man. She is practical to apply her own idea on love which develops naturally. It is man's part to find out woman's sincere feelings in the matter of love. It is woman's dignity not to show the exact feelings to a man in the first chance. Love relation is a matter of understanding. Moreover, she does not hand over the happiness of marriage to a matter of chance. Elizabeth's refusal of Mr. Collins's marriage proposal raises the honour of woman world and makes her contrastive to traditional woman as determined and respected woman. She holds woman's right position for establishing her own choice over a man. Her polite refusal to Mr. Collins, "I am very sensible of the honour of your proposals, but it is impossible for me to do otherwise than decline them" (90) proves that a female has her own view on choosing her husband which person he would be. She is not impractical to leave marriage relationship on a matter of chance. Her thinking on marriage, not a financial security for a woman but a place of happiness and love, establishes the respected position of woman, "I am not one of those young ladies... who are so daring as to risk their happiness on the chance of being asked a second time. I am perfectly serious in my refusal- You could not make me happy" (90). To defend Mr. Collins's view on "the true delicacy of the female character" (91), her view- she is not an elegant female but "a rational creature speaking the truth from her heart" (91)- heightens the dignity and rationality of a woman. She places herself beyond the typical thought of the society about woman. She can be a rational as any other man. Tanrivermis also states that "... Elizabeth's independence as: Elizabeth's views on marriage, on society, and her own position in society reflect her independent spirit and her critical intelligence...." Then her view exchange to her father on this matter proves the management power of a woman "whose behaviour at least could not be mistaken for the affection and coquetry of an elegant female" (92). Charlotte's engaging to Mr. Collins with a view to gaining "worldly advantage" (105) and "imaginable happiness" (105) gives a pang of pain for "a friend disgracing herself and sunk in her esteem" (105). As a representative of female world, she becomes disappointed for the reason of woman's integrity to sacrifice her to tolerable happiness in marriage life. She thinks that a woman "shall not, for the sake of one individual, change the meaning of principle and integrity nor endeavour to persuade yourself or me, that selfishness is prudence, and insensibility of danger, security for happiness" (115). She deplores on the real marriage situation of Charlotte that Charlotte has nothing own but her place is occupied by Lady Catherine and her daughter, "I expected at least that the pigs were got into garden, and here is nothing but Lady Catherine and her daughter!"(132).

Moreover, as a representative of normative feminism, Elizabeth shakes woman world to laugh off the insult of Darcy in Netherfield Park party by narrating the incident to her friends with great amusement. As having "a lively, playful disposition" (13), she is bold enough to make man's comment on her poor impression ridiculous. She determines to refuse Darcy's offer of dancing for believing him to act out of mere politeness because she overhears his conversation with Bingley, "she is tolerable; but not handsome enough to tempt me" (13). She as a woman does not want to attach herself with man who has no regard for her. Not only that, again her refusal to dance with Darcy at the time Bingley's sister singing at the piano is to think of it as his distaste of dancing and country living. This refusal dignifies the woman's position in society though Darcy is bewitched by "sweetness and archness in her manner" (46).She proves that a woman with liveliness, politeness, natural and pleasurable behaviour and honesty can attract anyone as Darcy is attracted by her. Moreover, she attracts Darcy not by eulogizing him but by taking a sensible place as an independent self who has her own view, "I never ridicule what is wise or good. Follies and non-sense, whims and inconsistencies do divert me" (50). Her conversational encounters with Darcy by provoking, teasing and arguing prove that she is intellectually equal to Darcy, a man. In another case, by the refusal of Darcy's love proposal, Elizabeth ascends the position of woman to a superior way. Thus Elizabeth brings out feminist values of equality and sovereignty. So incensed is Elizabeth what she believes in the ruin of Jane's chances of happiness that she thinks Darcy's love offer is a kind of insult and is against his own reason, "why with so evident a design of offending and insulting me, you chose to tell me that you liked me against your will, against your reason, and even against your character?"(158). So, she is determined to reject the man who ruins 
"happiness of a most beloved sister?" (158).

Her rejection of Darcy without concerning his position and money and her own accomplishment is a challenging matter of her future but she does it for the sake of her sister's concern, her dignity and her search for the happiness in marriage. Avoiding all kinds of artificiality, she is in search of natural attitude from everyone. So in her visit to Pemberley House of Darcy, she is astonished of Darcy's character who "does not rattle away like other young man" (204). At this place, she is impressed by the evidence of natural taste which creates her sense of gratitude, respect for Darcy. But she not as a sensitive lover exposes her feelings and sentiments towards Darcy. Only after understanding Darcy's true feelings towards her, she hands over herself to Darcy holding own dignity and place. Nilsson says that "she genuinely knows and loves her husband as opposed to simply marrying for money or security". By her own credit, she holds her better and happy future with Darcy maintaining respected and esteemed relationship with him. Melz (2013) in "Ideal Gender Roles and Individual Self-Expression in the Novels Pride and Prejudice and Sense and Sensibility" points out that "Elizabeth does not disregard all social tradition, which would have ruined her, but instead she learns that a healthy cynicism can go along with this recognition and she is allowed to settle comfortably with Darcy". In the penultimate section of Pride and Prejudice, it is indicated that she is able to maintain and attain happiness and respectful position escaping discredit and misery by applying her own judgment, intelligence and her sense of value and dignity. Hirota (2013) in "The Rise of an Equal Marriage in Pride and Prejudice" exposes that "as activists as Elizabeth and Darcy are, Austen indicates that they will practice establishing an equal relationship...Cognition and courtship (in other words, reason and love)- turn out to be central to her maturation. It is in her dealings with eligible men that Elizabeth is tripped up by and finally fights herself free from the cognitive constraints of her community, and it is through her love for one of those men that she belongs to establish a new and better community".

In other way, in the male-oriented society, Sethe's life is that "being alive was the hard part" (7) because Sethe has nothing but "a tree on my back and a haint in my house, and nothing in between but the daughter I am holding in my arms. No more running- from nothing. I will never run from another thing on this earth" (15). Sethe's inhabitation of this world takes too much from her life without giving her any rights. Irfan also exposes that "Beloved provides an insight into the structure and working of the plantocracy that denied a woman her basic human and political rights". That's why, Sethe has to suffer from a brutal beating from her male masters. The physical assault draws a tree on her back composed of beating's scars, "a Chokecherry tree. Trunk, branches, and even leaves" (16) and it looks like " the sculpture her back had become, like the decorative work of an ironsmith too passionate for display" (17). The white man's scar as tree on her back becomes a permanent scar "in her rebellion brain" (70). As an object of making sex to man, Paul D, her fellow slave in Sweet Home, has sex with Sethe not out of love for her, even he is disgusted by the scars on Sethe's back and flabby breasts. As a woman Sethe's only working place confines in kitchen as she does in Sweet Home. Her only work is to cook food and bring food to male niggers in the field. Paul D's thinking to have a baby of him from Sethe shows that Sethe again falls into male consideration -woman is the centre of child-birth, not a lovepartner which is needed for Sethe's life.

In the male dominated society, Sethe cannot fulfill her marriage dream as a girl, "I found out there wasn't going to be no ceremony, no preacher. Nothing" (58) and "it was all right for us to be husband and wife and that was it. All of it"(59). She can only meet her husband in daylight on Sunday morning. Her marriage ceremony includes only her ownmade dress and her first coupling with her husband, Halle, in a cornfield. She is so much occupied by male-oriented society' fence that she has no any strong and practical dream to unite her own children- Buglar, Howard, and Denver. Although she is dreaming to "see the face burning in the sunlight" (132), she is cruelly entangled by this male-centred society and tramps into unaltered future which brings her mental sickness. So, Sethe as woman and slave has no any pleasant memory, but "every mention of her past life hurt" (58) and "everything in it was painful and lost" (58). Sethe's belief on "there is no world outside my door" (184) is for the oppressive force of white patriarchy. And her whole life is covered with pain "the hurt was always there- like a tender place in the corner of her mouth that the bit left" (58). She is trapped in past and male community. Sethe is accustomed to live in a male-patronizing society who has no future. She has to lead a life in the mercy of male society. Without future thinking, she is used to living without exercising her own self, "today is always here, tomorrow never" (60). Depression forces her not to think of her future because male mechanism loads her brain with so many painful past, "her brain was not interested in the future. Loaded with the past and hungry for more, it left her no room to imagine, let alone plan for, the next day" (70). For her brain blocked by society's pressure, Sethe is not able to utilize Paul D's hand to achieve her own gain. She is oriented to lead a life in male guidance and thought, "now he had added more: new pictures and old memories that broke her heart" (95). Moreover, this male society makes her disbeliever of male promise, "she didn't believe any of them" (128). Though she tries to hold her position in the popular society and revive her life, "to launch her newer stronger life with tender man" 
(99) and " she wanted Paul D"(99) in her life, she dramatically away from her own choice falls in the hand of femaleneglected society and crushes herself in a dark situation. At last, she effaces her individual identity by being a possession of Beloved, "in her insistence on absolute possession of her mother, Beloved resurrects the slave master's monopoly over word and body...." Sethe's desire to know all what happened stops at a point "beyond which she would not go" (36, 37).

Sethe is surrounded by so many strong male fence that even her husband, Halle witnesses his wife, Sethe's seduction, but he does not do anything because it is common occurrence to a man. She is failure to attain any respect, security and love from her husband. In Miquel-Baldellou's(2012) "The Beloved Purple of their eyes: Inheriting Bessie Smith's Politics of Sexuality", it is notified that "Sethe remembers that her husband Halle treated her in a brotherly way, but she reflects on the fact that love necessarily implies being able to make demands, have expectations and lay claim to the other" (Miquel-Baldellou). Even after many years, when she is informed of her husband's knowledge of her seduction, she tries to raise her voice to ask a question why he does not do anything in that time. She is stopped by another man Paul D, "a man ain't a goddamn ax. Chopping, hacking, busting every goddamn minute of the day. Things got to him. Things he can't chop down because they're inside" (69).She then walks only following male guidance with surprise and despair. She is worried for her future, "worry... about tomorrow, about Denver, about Beloved, about age and sickness not to speak of love" (70). She has not have any place of showing her love for anyone. So, Morrison shows Sethe as woman who has initiatives but has to leave her situation to the hand of woman's destiny. She does not find out the exact situation of her husband although she is sure of his fleeing from Sweet Home, "if I made it, Halle sure can". Even, to her, Paul D's intension to go away from her is a natural matter and it is a matter destiny, "and whatever the reason, it was all right. No fault. Nobody's fault" (128), because male domination destroys her correlative sense of identity. Through her life she proves Baby Suggs's conclusion that "there is no bad luck in the world but white folks" (89). So, Sethe's "twenty-eight happy days were followed by eighteen years of disapproval and a solitary life" (173). Pleasure of freedom and dreaming of getting permanent freedom snatch away her long-lasting independence and fells her in the depth of subjugation hole. Raising voice for real woman self is a crime to this society. The unloving male society isolates her and Denver.

The unsympathetic male society gives her punishment of eighteen years of isolated life which banishes her mentality to search the freedom and destroys her control over own mind. Her motherhood concept and so many male hindrances pave her way to be entangled by the ghost, "when I tell you mine, I also mean I'm yours" (203). She shows that she cannot draw breath without her children and only identifies herself as a mother. Irfan (2002) in the introduction of Toni Morrison's Beloved, a reader's companion unearths that "Beloved develops the idea that maternal bonds can harm a woman's sense of self" (Ifran). Recurrent memories of past events add a new horror to her life and an indication of her total destruction. Though the surrounding people rescues Sethe from the attachment of ghost and the ghost is disappeared , Ella , a rescuer of fugitive, doubts the ghost's disappearance " maybe... maybe not"(263). Denver's thinking "I've lost my mother" (266) and Sethe's final resolution, "I don't have no plans. No plans at all" (272) give a little chance of recovery. The impossibility of making plans is linked with the power of memories of the past. But Paul D's declaration that he and Sethe must create "some kind of tomorrow" (273) expresses the hope. Sethe's repeated surprising question "Me? Me?"(273) against Paul D's inspiration of Sethe "you your best thing, Sethe, you are" (273) reveals that she has nothing left to stand up and has no preparation for attaining her self-authorship and reconnecting with community . Her success totally depends on Paul D's trustworthy deeds. At last her life relies on the mercy of Paul D or any male planning. Mayfield also gives her opinion that "... the search in Sethe's mind for her origins cause Sethe to contemplate her existence, and this search for origins prepares Sethe for her attempts to accept the 'Other' in her life the white folks who have little concern about her origins but who wish to plan her future for their own good".

IV

Elizabeth embraced with normative feminism places herself as equal as man by possessing all qualities as man has according to justice and morality. She is able to give completion of her initiatives and intension holding her control over situation. Elizabeth has own consideration on prevailing situation, not complying on the imposed conclusion. Relying on her own judgment not sensitivity, she accepts the present thing without surprise and manages the situation. But Sethe incarnated by descriptive feminism can not give a completion of her initiatives to get freedom and her intension to create own life because the prevailing male controlled society surrounds her as octopus. Sethe possessed with Elizabeth like equality sense, determination and thinking to live without any help from man does not see the success of these initiatives. Her life is the possession of male society. In her slave life, she is under her masters, school teacher and her nephews. Her intention, wish and will are not recognized and expressed. When she escapes from the woman prison, the 
male society again comes to claim their ownership-to get back their pet animal and thing, Sethe and her children. But, her attempt to rescue her children by cutting throat of Beloved jails her in concrete fence ignoring her real cause. At last, the male community does not recognize her as an individual self, so they throw away her from their society. In slavery, her life is in hell and she is treated as animal ignoring her sense but after the infanticide, the cruel male society does not recognize even her existence and counts no one of their community though she has many potentialities and qualities as Elizabeth has.

The critical overview of this paper reveals in conclusion that Jane Austen presents Elizabeth through her all actions as a woman self with individuality and equality in a society. Her practical personality and her sense of value establish woman's equality with man and prove that not only man but woman can do anything for society and family without ignoring her own dignified sense. In "Analysis of the Feminism in Pride and Prejudice", Xueqing Wang (2012) rightly says that "In this way, Austen successfully deconstructs the male's voice and establishes feminist narrative authority. Austen's writing itself is a rebellious act against the patriarchal rumor of the female intellectual inferiority and duping regulation of women's proper behaviors" (Wang). In the same time, Elizabeth, like woman, has to transform herself as Sethe who has to undergo many sufferings of merciless and brutal man-made society as Sethe, like woman, has to. Sethe having so many potentialities to make her own life, falls in the mercy of male society. I think, Sethe is not able to break the anti-woman's boundary of society and to create her way of woman society. Even, she makes herself victimized of the male occupied society. And ultimately, Sethe, like woman, becomes distracted for the pressure of her surrounding woman disadvantaged and unequal society which is real fate of woman.

\section{References}

Abrams, M. H. ed. A Glossary of Literary Terms (1993). India: Prism Books PVTLTD.

Adhikari, Madhumal (2002).“The Female Protagonist's Search for Wholeness and Toni Morrison's Discourse in Beloved”. Ed. Ayesha Ifran. New Delhi: Asia Book Club.

Austen, Jane. Pride and Prejudice (1813). London: Penguin Books Ltd.

Banumathi, N (2012). "African American Feminist consciousness in Toni Morrison's

Beloved". [Online] Available: banumathibelovedmorrisonfinal.pdf.- Adobe Reader( October 12, 2012).

Bjork, Patrick Bryce ( 1992). The Novels of Toni Morison: The Search for Self and Place with the Community. New York: Peter Lang Publishing, Inc.

"Call Me My Name: The Role of Nomenclature in Toni Morrison's Beloved . [Online] Available: Remer.pdf-Adobe Reader( January 12, 2013).

Costa, Elza de Fatema Dissenfa (2012). "Unspeakable Things (Un) spoken: the representation of Black Women in Toni Morrison's Beloved". [Online] Available: (D\%2\%20COSTA,\%20ELZA\%20DE\%20FATIMA\%20DISSENHA.pdf-AdobeReader) ( October 12,2012).

Daniel, Kristin Sue (2013). "Power and its Price: Female roles and the consequences of gaining agency in Toni Morrison's Beloved and Jane Smiley's A Thousand Acres. [Online] Available: http://lib.dr.iastate.edu/cgi/viewcontent.cgi?article=2414\&context=etd( July $6,2013)$.

Dueker, Kerry (2012)." When a Man Becomes a Woman (And Vice Versa). [Online] Available: http:// /www.millikin.edu/english /beloved/Dueker- feminist-essay1.html ( September 14, 2012) .

Grewal, Gurleen. Circles of Sorrow, Lines of Struggle (1998) .Baton Rouge: Louisiana State University Press.

Heinert, Jennifer Lee Jordan(2008). Narrative Conventions and Race in the Novels of Toni Morrison. New York: Routledge.

Hirota , Mirei (2013). "The Rise of an Equal Marriage in Pride and Prejudice". [Online] Available: (http://www.lib.geidai.ac.jp /MBULL/33Hirota.pdf ( January 24, 2013).

Hooks, Bell(1982). Ain't I a Woman: Black Woman and Feminism. Padstow: Pluto Press.

Horvitz, Deborah (1989). "Nameless Ghost: Possession and Dispossession in Beloved". Studies In American Fiction, Vol. 17, No. 2, Autumn( 157-67). "Introduction: Theories of the Fantastic and feminist Narrative Theory- An Intersection". [Online] Available: 978-0-7864-361- 6.Introduction.pdf.Adobe Reader ( October 12, 2012).

Irfan, Ayesha, ed (2002). Toni Morrison's Beloved, a reader's companion.

Introd. NewDelhi: Asia Book Club.

Maitrise, Memoire de (2013). "The Multidimensionality of the Woman's Victim hood in Toni Morrison's Beloved and Bessie Head's A Question of Power". [Online] Available:THL2471.pdf-Adobe Reader ( January 15, 2013).

Mayfield, Sandra ( 2013). "Motherhood in Toni Morrison's Beloved: A Psychological Reading". [Online] Available: Motherhood_in_Toni _Morrison_Beloved.pdf-Adobe Reader (January 14, 2013).

McDaniels, Preselfannie W.(2013). "Mothering Modes: Analyzing Mother Roles in Novels by Twentieth-Century United States Women Writers". [Online] Available: McDaniel-dis. Pdf- Adobe Reader( January 13,2013).

Melz, Sarah (2013). "Ideal Gender Roles and Individual Self-Expression in the Novels Pride and Prejudice and Sense and Sensibility". [Online] Available: (https://mospace.umsystem.edu/xmlui/bitstream/handle/10355/10691/ (January 23, 2013). 
Miquel-Baldellou, Marta (2012). " The Beloved Purple of their eyes: Inheriting Bessie Smith's Politics of Sextuality". [Online] Available: mmiquel@dal.udl.es ( June 6, 2012).

Morrison, Toni. Beloved(1987). USA: PICADOR.

Muji, Arbnore ( 2012). "Gender issues reflected with nature in Jane Austen's novelPride and Prejudice". [Online] Available:FULLTEXT01(1).pdf- Adobe Reader ( September 23, 2012).

Nilsson, Kristina(2012) . "The accomplished Woman- No Changes Accomplished? A comparison of the Portrayal of woman in Jane Austen's Pride\& Prejudice and Helen Fielding's Bridget Jones". [Online] Available: FULLTEXT01.pdf- Adobe Reader (October 23, 2012).

Plasa, Carl, ed. Toni Morison's Beloved (1998). "My Girl Come Home: Reading Beloved". Cambridge: Icon Books Ltd.

Primlyn, Linda A.( 2013). "The Concept of Blackness In Toni Morrison's Beloved" . [Online] Available: http://worldlitonline.net/5-lindathe-concept.pdf (January 14, 2013).

Swords, Barbara W (2012). "Woman's Place in Jane Austen's England". [Online] Available: http://www.jasna.org/persuasions/printed Inumber10/swords.htm (December 24,2012).

Tanrivermis, Mihriban (2013). "Female Voice in Jane Austen: Pride and Prejudice and Emma". [Online] Available: (https://etd.lib.metu.edu.tr/upload/12606716/index.pdf ( January 23, 2013).

"Topics in Feminism. Stamford Encyclopedia of Philosophy. [Online] Available: http://plato.stanford.edu/entries/feminism-topics/( January 24, 2013).

Wang ,Xueqing(2012). "Analysis of the Feminism in Pride and Prejudice". [Online] Available:richerwang1980@yahoo.com ( June 8, 2012).

"What is feminist literary criticism? How does this apply to Pride and Prejudice?". [Online] Available: http://chsaplitprideandprejudice.weebly.com /feminism.html ( June 26, 2012). 